\title{
Incentive Spirometry dan Chest Therapy Efektif Dalam Mengurangi Kekambuhan Pada Kondisi Asma Bronkial
}

\author{
Diki Ananda ${ }^{1)}$, Nova Relida Samosir ${ }^{2)}$ \\ ${ }^{1,2)}$ Program Studi D-III Fisioterapi Fakultas Kedokteran dan Ilmu Kesehatan \\ Universitas Abdurrab \\ Jl. Riau Ujung no. 73 Pekanbaru \\ email : nova.relida@univrab.ac.id
}

\begin{abstract}
Background: Asthma bronchiale is a chronic respiratory disease that be marked inflammation chronic respiratory that involve kind of inflammation cell and mediators that interact wich each other so that produce physiogical changes and respiratory structure. Prevalence asthma case in Indonesia based on research result basic health (RISKESDAS) on 2013 to show that age 25-34 years have prevalence asthma the highest 5,7\% and age under lyear prevalence asthma lowest of 1,5\%. This research purposes to know the effectiveness gived Incentive spirometry and chest therapy to reduced symptoms recurrence that be measured by asthma control test and incentive spirometry. Research methods in case study that served in the form descriptive narrative. This research subject consist of one asthma bronchial sample with persistent degree moderate that fulfill criteria sample/ research. This is done 16 times therapy begins at date 04 february 2020 until 02 april 2020 in labotary manual therapy 1 D-III physiotherapy of Abdurrab University. Result: Evaluation with use asthma control test is obtained results is descreased symptoms recurrence and ecnhanment asthma control test from score 16 (Uncontrolled asthma) to be score 22 (Partially controlled asthma). Conclusion of the case study modality Incentive spirometry and chest therapy the results isthat decreased symptoms recurrence and increased of value force vital capacity $(F V C)$ and force expired volume in one second $\left(F E V^{I}\right)$ on lung function
\end{abstract}

Keywords : Asthma bronchiale, Incentive Spirometry, Chest Therapy, Postural Drainage, Tapotement, Asthma

Control Test (ACT)

Abstrak

Latar Belakang: Asma bronchial merupakan penyakit respiratorik yang ditandai inflamasi kroniks aluran napas yang melibatkan bermacam sel inflamasi dan mediator yang saling berinteraksi sehingga menghasilkan perubahan fisiologis dan struktur jalan napas. Prevalensi kasus asmadi Indonesia berdasarkan hasil riset kesehatan dasar (RISKESDAS) tahun 2013 menunjukkan bahwa umur 25-34 tahun mempunyai prevalensi asma tertinggi sebesar 5,7\% dan umur $<1$ tahun memiliki prevalensi asma terendah sebesar $1,5 \%$. Tujuan penelitian ini untuk mengetahui efektivitas pemberian Incentive Spirometry dan Chest Therapy untuk mengurangi gejala kekambuhan yang diukur dengan Asthma Control Test dan Incentive Spirometry. Metode penelitian adalah studi kasus yang disajikan dalam bentuk narasi deskriptif. Subjek penelitian ini terdiri dari satu sampel Asma bronchial dengan derajat persisten sedang yang memenuhi kriteria sampel/ penelitian ini dilakukan 16 kali terapi dimulai pada tanggal 04 februari 2020 s/d 02april 2020 di Laboratorium Manual Terapi I DIII Fisioterapi Universitas Abdurrab. Hasil: Evaluasi dengan menggunakan Asthma Control Test didapatkan hasil adanya penurunan gejal akekambuhan dan peningkatan kontrol asma dari skor 16 (asmatidakterkontrol) menjadi skor 22 (asma terkontrol sebagian). Kesimpulan studi kasus penggunaan modalitas Incentive spirometry dan Chest therapy didapatkan hasil bahwasanya terjadi penurunan gejala kekambuhan dan peningkatan nilai force vital capacity (FVC) dan force expired volume in one second ( $\mathrm{FEV}^{1}$ ) pada fungsi paru-paru.

Kata kunci :Asma bronchial persisten sedang, Incentive Spirometry, Chest therapy, Postural Drainage, Tapotement, Asthma Control test (ACT) 


\section{Pendahuluan}

Asma bronkial merupakan penyakit respiratorik yang ditandai oleh peradangan saluran nafas, obstruksi jalan napas reversible, hipersekresi lendir, dan hipersensitivitas saluran napas. Dalam proses radang jalan napas asma direspon berbagai sel, eosinophil, limfosit $T$, sel mast, neutrophi, dan sel dendritik $^{(1)}$.

Asma bronkial menunjukkan inflamasi kronik saluran napas yang melibatkan bermacam sel inflamasi dan mediator yang saling berinteraksi sehingga menghasilkan perubahan fisiologis dan struktur jalan napas. Inflamasi kronik tersebut berhubungan dengan hiperresponsif jalan napas yang merujuk pada suatu episode berulang dari mengi, sesak napas, kaku dinding dada, dan juga batuk ${ }^{(2)}$.

Tanda dan gejala yang khas pada kondisi asma bronkial antara lain (a) tanda sesak napas dimana penderita sulit untuk berbicara dalam kalimat yang penuh, sulit berjalan, dada terasa sesak dan mudah letih, (b) bernapas dengan berusaha, bahu naik dengan bernapas, leher dan tulang rusuk bergerak ke dalam dengan bernapas, cepat, pernapasan tidak nyaman, batuk siang dan/ malam hari, mengi, (c) pikiran berubah-ubah, penderita sulit berpikir dengan jelas, bingung, kehilangan kewaspadaan, (d) oksigen yang rendah, yang membuat bibir abu-abu atau biru, jari telunjuk biru atau abu-abu, (e) nilai PEF (arus puncak respirasi) rendah, $\mathrm{PEF}<60 \%$ terbaik personal, (f) obat-obatan "tidak bekerja" PEF gagal naik setelah menggunakan obat yang bekerja untuk melegakan pernapasan, dan gejala berlanjut.

Faktor lingkungan memegang andil dalam memicu asma bronkial yaitu sensitasi dini oleh alergen, irritan, dan polutan. Alergen adalah zat yang menyebabkan gejala penyakit asma dengan cara memunculkan reaksi alergi. Alergen penyakit asma yang umum diantaranya: serbuk sari (bunga), hewan, dan tungau debu rumah. Iritan adalah zat yang menyebabkan gejala penyakit asma dengan cara menganggu saluran pernapasan. Iritan penyakit asma yang umum diantaranya: udara dingin, asap rokok, dan asap sisa pembakaran hutan $^{(3)}$.

\section{Tinjauan Pustaka}

\subsection{Kekambuhan pada Asma Bronkial}

Asma bronkial adalah inflamasi dari saluran pernapasan yang melibatkan interaksi kompleks dari sel, mediator-mediator, sitokin, dan kemokin. Asma bronkial adalah gangguan peradangan di saluran pernapasan kronis yang terjadi pada tingkatan sel dan elemen selular. Peradangan kronis yang terjadi pada kondisi asma dikaitkan dengan obstruksi aliran udara yang meluas dan bervariasi dalam paru-paru.

Kekambuhan asma yaitu kembalinya gejala-gejala asma bronkial sehingga cukup parah dan menganggu aktivitas sehari-hari dan memerlukan rawat inap dan rawat jalan yang tidak terjadwal. Frekuensi kekambuhan asma bronkial ini dapat meningkat secara berkala. Kekambuhan asma dapat dipengaruhi oleh beberapa faktor, misalnya asap rokok, binatang peliharaan, jenis makanan, perabot rumah tangga yang berdebu, perubahan cuaca, dan juga kondisi stress. Kekambuhan asma masih sering terjadi meskipun telah dikelola secara efektif oleh kebanyakan penderita asma bronkial. Pengelolaan kondisi diperlukan untuk mengembalikan fungsi paru-paru agar bekerja optimal kembali dan meminimalkan mordibitas.

Berat ringannya kekambuhan asma ditentukan oleh berbagai faktor, antara lain gambaran klinik sebelum pengobatan (gejala, eksaserbasi, gejala malam hari, pemberian obat inhalasi $\beta-2$ agonis dan uji faal paru) serta obat-obatan yang digunakan untuk mengontrol asma (jenis obat, kombinasi obat dan frekuensi pemakaian obat). Klasifikasi asma pada orang dewasa saat tanpa serangan atau diluar serangan, terdiri dari 1) Intermitten, 2) Persisten ringan, 3) Persisten sedang, 4) Persisten berat.

Asma didefinisikan secara sederhana sebagai obstruksi jalan napas yang reversible. Reversible terjadi secara spontan atau dengan penanganan. Pengukuran dasar adalah 
kecepatan aliran puncak dan kriteria diagnosa berikut yang digunakan oleh Bristish Thoracic Society ${ }^{(4)}$.:

1. $\geq 20 \%$ perbedaan pada minimal tiga hari dalam seminggu selama minimal 2 minggu

2. $\geq 20 \%$ perbaikan aliran puncak setelah penanganan, misalnya: (a) sepuluh menit agonis $\beta$ inhalasi (salbutamol), enam minggu mengonsumsi kortikosteroid inhalasai (beclometasone), empat belas hari mengonsumsi $30 \mathrm{mg}$ prednisolone.

3. $\geq 20 \%$ penurunan aliran puncak setelah pajanan terhadap pemicu

Peningkatan kekambuhan dipicu adanya reaksi inflamasi jalan napas sebagai respon eosinophilic, sel limfosit $\mathrm{CD}+4$, sel mast. Peradangan jalan napas oleh eosinophilic mempunyai peran terbatas dalam pengembangan infiltrasi yang cenderung terakumulasi ke protein matriks dalam jaringan bronkial menyebabkan peningkatan sel-sel otot polos terhadap alergen. Selanjutnya, sel $\mathrm{T}$ teraktivasi melepas sitokin (IL-4, IL-5, IL-13) dan CD+4 sebagai mediasi respon $\mathrm{T}$ helper (Th2) untuk menginduksi produksi IgE, inflamasi cuonophilic, dan sekresi lendir ke saluran napas. Akibatnya terjadi obstruksi jalan napas dan menimbulkan reaksi berkelanjutan sel mast dengan melepaskan amphiregulinyang menginduksi sekresi lendir dan meminimalkan kerja otot polos ${ }^{(5)}$.

Hal tersebut menyebabkan $\mathrm{O}_{2}$ masuk ke paru-paru terbatas akibat kontraksi otot inspirasi dan ekspirasi minimal, penyempitan bronkus, penurunan Force Expired Volume in one second (FEV'1), Forced Vital Capacity(FVC), serta rasio $\mathrm{FEV}^{1}$ dan $\mathrm{FVC}^{(6) .}$

\subsection{Metode dan Teknik Intervensi a. Incentive spirometry}

Incentive spirometry adalah metode napas dalam yang memungkinkan visualisasi atau feedback hasil aliran inspirasi atau volume.
Visualisasi hasil volume ini dapat memotivasi pasien melakukan inhalasi perlahan-lahan dan dalam dengan benar untuk memaksimalkan inflasi paru dan mencegah atau mengurangi kejadian atelekstatis. Idealnya pasien dalam posisi semi-fowleratau dudukuntuk menambah ekskursi diapragma, namun demikian dapat dilakukan dalam berbagai posisi pasien. Incentive spirometry ada 2 tipe: aliran volumetric flow, tipe ini tidal volume spirometri dengan memastikan volume udara yang dihirup, dimana makin dalam pasien bernapas maka volume makin bertambah. Pasien melakukan napas dalam melalui pangkal pipa yang ditempelkan di mulut, berhenti sejenak saat puncak inflasi paru dilanjutkan relaksasi dan ekhalasi. Lakukan napas normal beberapa kali sebelum melakukan serial napas dalam yang berikutnya untuk menghindari kelelahan. Volume akan bertambah sesuai toleransi. Spirometri aliran, dengan tujuan yang sama dengan spirometry aliran volume tetapi tidak dilakukan preset volume. Spirometer berisi bola-bola yang bergerak terdorong $\mathrm{ke}$ atas oleh kekuatan pernapasan dan bergantung di udara ketika pasien menarik napas. Jumlah udara yang dihirup dan aliran udara di estimasi dengan seberapa panjang dan seberapa tinggi pergerakan bola-bola yang bergantung ${ }^{(7)}$.

\section{a. Teknik Pelaksanaan}

Latihan dilakukan setiap hari sebanyak 5 kali sehari, dengan 10 set, di antaranya istirahat selama 15 detik selama 8 minggu di rumah subjek penelitian. Catat waktu dan jumlah volume maksimal serta ditandatangani oleh penderita dan saksi setiap kali melakukan latihan pada buku monitoring harian. Volumetric incentive spirometry telah digunakan sebagai pengganti untuk upaya pernapasan dalam dan berkorelasidengan berbagai hasil klinis, utilitasvolumetric incentive spirometry yang ditargetkan dapat sebagai metode pemantauankemajuan pasien global dan mempromosikan keterlibatan pasien ${ }^{(8)}$. 


\section{b. Mekanisme Penurunan Kekambuhan Pada Asma Bronkial}

Volumetric spirometry menfasilitasi napas dalam yang lambat dan berkelanjutan melalui aliran atau volume yang diinginkan telah tercapai. Dasar dari incentive spirometry melibatkan pasien mengambil inspirasi maksimal dan berkelanjutan atau sustained maximal inspiration (SMI) adalah inspirasi yang lambat dan dalam dari kapasitas sisa fungsional hingga kapasitas paru total, diikuti oleh $>5$ detik tahan napas. Cara latihan dengan incentive spirometry tipe volumetric dimana subjek penelitian duduk dalam posisi tegak, alat volumetric incentive spirometry dipegang dengan salah satu tangan pada posisi berdiri tegak, letakkan mouthpiece ke dalam mulut diantara gigi dengan bibir terkatup rapat-rapat mengelilingi mouthpiece, lakukan pernapasan biasa 3 kali, tarik napas sekuatnya dengan bibir terkatup rapat mengelilingi mouthpiece dan ditahan 3-5 detik. Usahakan indikator piston bergerak setinggi-tingginya semampu penderita (menunjukkan jumlah volume inspirasi yang dapat di capai), bagian atas dari indikator kuning (bola kuning) harus berada pada posisi kotak tersenyum, setelah itu lakukan buang napas (ekspirasi) perlahanlahan, lepaskan mouthpiece dari mulut dan dianjurkan untuk batuk setelah menyelesaikan latihan. Latihan dapat di hentikan jika terasa pusing dan sesak.Kontraindikasi incentive spirometry terbagi dalam kontra indikasi absolut dan relatif. Kontraindikasi absolut meliputi: Peningkatan tekanan intrakranial, space occupying lesion (SOL) pada otak, ablasio retina, dan lain-lain. Sedangkan yang termasuk dalam kontraindikasi relatif antara lain: hemoptisis yang tidak diketahui penyebabnya, pneumotoraks, anginapektoris tidak stabil, hernia skrotalis, hernia inguinalis, hernia umbilikalis, Hernia Nucleous Pulposus (HNP) tergantung derajat keparahan, dan lainlain ${ }^{(9)}$.

\section{b. Chest Therapy}

Merupakan tindakan drainase postural, pengaturan posisi, serta perkusi dan vibrasi dada yang merupakan metode untuk memperbesar upaya klien dan memperbaiki fungsi paru ${ }^{(10)}$. Chest therapysangat berguna bagi penderita penyakit paru yang bersifat akut dan kronis, sangat efektif dalam upaya mengeluarkan sekret dan perbaikan ventilasi pada pasien dengan gangguan fungsi paru. Mengembalikan dan memelihara fungsi otototot pernapasan dan membantu mengeluarkan sekret dari bronkus dan untuk mencegah penumpukan sekret. Chest therapy dapat digunakan untuk pengobatan dan pencegahan pada penyakit paru obstruksif menahun, penyakit napas restriktif karena kelainan neuromuscular dan parenkim paru seperti fibrosis dan pasien yang mendapat ventilasi mekanik $^{(11)}$.

\section{1). Postural Drainage}

Memposisikan pasien sedemikian rupa sehingga dengan pengaruh gravitasi, cairan atau lendir dapat mengalir ke lobus utama. Jadi dalam posisi tersebut, lobus yang akan di drainase pada posisi lebih tinggi dari bronkus utama yang tentu saja perlu disesuaikan dengan arah-arah bronchial tree untuk mendapatkan hasil yang optimal ${ }^{(12)}$.

Postural drainage suatu bentuk pengaturan posisi pasien untuk membantu pengaliran mukus sehingga mukus akan berpindah dari segmen kecil ke segmen besar dengan bantuan gravitasi dan akan memudahkan mukus diekspektorasikan dengan bantuan batuk ${ }^{(13)}$.

Penelitian yang dilakukan oleh Purnomo di RSP dr. Arie Wirawan Salatiga pada bulan februari tahun 2014 dengan tindakan terapi terhadap 8 orang penderita asma dengan pemberian postural drainage, tapotement, dan batuk efektif sebanyak 6 kali terapi dengan waktu 10-20 menit efektif berpengaruh terhadap penurunan sesak nafas dengan evaluasi menggunakan Borg scale ${ }^{(14)}$. 


\section{a. Mekanisme postural drainage}

Membantu mengeluarkan sekresi dari paru-paru dan mengurangi hambatan pada dada. Posisi postural drainage yang berbeda dipertahankan dengan bantuan bantal dan selimut selama 5-15 menit dan selama posisi ini, teknik tapotement digunakan untuk melonggarkan sekresi ${ }^{(15)}$. Sesak napas selain karena adanya penumpukan sputum pada lobus baru juga mengakibatkan tidak efektifnya pernapasan. Sputumyang sulit dikeluarkan dapat dikurangi dengan diberikan postural drainage, tapotement dan latihan batuk efektif. Postural drainage dan tapotement yang bertujuan untuk mengeluarkan mukusdari segmen paru dengan bantuan gravitasi dan melepaskan sputum dari dinding paru-paru ${ }^{(16)}$.

Dalam pelaksanaanya postural drainage. Ada beberapa posisi yang digunakan saat melakukan postural drainageyaitu:

\subsection{Pemeriksaan dan Pengukuran (Asthma controls test)}

Asthma control test terdiri dari 5 pertanyaan yang telah diuji validitasnya dan dikeluarkan oleh American Lung Association (ALA) untuk mengevaluasi kontrol asma pada pasien dan mendeteksi perburukan penyakit hal tersebut berdasarkan gejala harian, gejala malam, hambatan aktifitas, penggunaan obat pelega serta penilaian sendiri pasien terhadap penyakitnya. Pemakaiannya dianjurkan dan pemberian skor setiap jawaban pertanyaan dengan nilai skor 1 sampai 5. Nilai maksimal adalah 25 dengan pembagian sebagai berikut: (a) skor 19 atau kurang = asma tidak terkontrol, (b) skor 20-24= Asma terkontrol sebagian, (c) skor $25=$ Asma terkontrol. Penggunaan asthma control test dapat meningkatkan kualitas komunikasi antara tenaga kesehatan dan pasien karena pertanyaan pada ACT jelas dan konsisten, sehingga pasien lebih terbuka dan dapat menjawab pertanyaan dengan jujur. Validitas ACT dapat ditingkatkan dengan menggunakan spirometri serta penilaian ahli. Tingkat sensitifitas ACT adalah $68,4 \%$ dan spesitifitas $76,2 \%{ }^{(17)}$.
Tabel 2.5 Asthma control test kuisoner

\begin{tabular}{|c|c|c|c|c|c|c|}
\hline Quisoner & 1 & 2 & 4 & & 5 & Score \\
\hline $\begin{array}{l}\text { Dalam } 4 \text { minggu } \\
\text { terakhir, berapa } \\
\text { banyak waktu asma } \\
\text { yang mencegah anda } \\
\text { menyelesaikan } \\
\text { banyak pekerjaan, } \\
\text { sekolah, atau di } \\
\text { rumah? }\end{array}$ & $\begin{array}{l}\text { Set } \\
\text { iap } \\
\text { wa } \\
\text { ktu }\end{array}$ & $\begin{array}{l}\text { Seba } \\
\text { gian } \\
\text { besa } \\
\text { r } \\
\text { wakt } \\
\text { u }\end{array}$ & $\begin{array}{ll}\text { Be } & \text { Sedi } \\
\text { ber } & \text { kit } \\
\text { apa } & \\
\text { wa } & \\
\text { ktu } & \end{array}$ & $\begin{array}{l}\mathrm{Ti} \\
\text { ad }\end{array}$ & & \\
\hline $\begin{array}{lr}\text { Selama } 4 & \text { minggu } \\
\text { terakhir, } & \text { seberapa } \\
\text { sering } & \text { anda } \\
\text { mengalami } & \text { sesak } \\
\text { napas? } & \end{array}$ & $\begin{array}{l}\text { Le } \\
\text { bih } \\
\text { dar } \\
\text { i } \\
\text { seh } \\
\text { ari }\end{array}$ & $\begin{array}{l}\text { Seka } \\
\text { li } \\
\text { seha } \\
\text { ri }\end{array}$ & $\begin{array}{l}3-6 \text { kali } \\
\text { semingg } \\
\text { u }\end{array}$ & $\begin{array}{l}1-2 \\
\mathrm{kal} \\
\mathrm{i} \\
\mathrm{se} \\
\mathrm{mi} \\
\mathrm{ng} \\
\mathrm{gu}\end{array}$ & $\begin{array}{l}\text { Tid } \\
\text { ak } \\
\text { sa } \\
\text { ma } \\
\text { sek } \\
\text { ali }\end{array}$ & \\
\hline $\begin{array}{l}\text { Selama } 4 \text { minggu } \\
\text { terakhir, seberapa } \\
\text { sering gejala asma } \\
\text { anda (mengi, batuk, } \\
\text { sesak napas, sesak } \\
\text { dada) } \\
\text { membangunkan } \\
\text { dimalam hari atau } \\
\text { lebih awal di pagi } \\
\text { hari? }\end{array}$ & $\begin{array}{l}4 \\
\text { sa } \\
\mathrm{mp} \\
\text { ai } \\
\text { leb } \\
\text { ih } \\
\text { dal } \\
\text { am } \\
\text { se } \\
\text { mi } \\
\text { ng } \\
\text { gu }\end{array}$ & $\begin{array}{l}2-3 \\
\text { mala } \\
\mathrm{m} \\
\text { per } \\
\text { min } \\
\text { ggu }\end{array}$ & $\begin{array}{l}1 \quad \text { kali } \\
\text { semingg } \\
\text { u }\end{array}$ & $\begin{array}{l}1-2 \\
\text { kal } \\
\mathrm{i}\end{array}$ & $\begin{array}{l}\text { Tid } \\
\text { ak } \\
\text { ada }\end{array}$ & \\
\hline 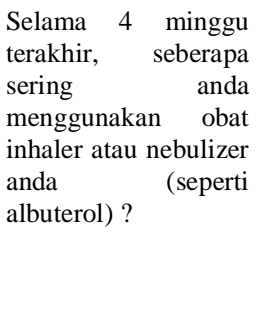 & $\begin{array}{l}\text { Le } \\
\text { bih } \\
\text { dar } \\
\text { i } 3 \\
\text { kal } \\
\text { i } \\
\text { per } \\
\text { har } \\
\text { u }\end{array}$ & $\begin{array}{l}1 \\
\text { sam } \\
\text { pai } 2 \\
\text { kali } \\
\text { per } \\
\text { hari }\end{array}$ & $\begin{array}{l}1 \quad \text { kali } \\
\text { perming } \\
\text { gu }\end{array}$ & $\begin{array}{l}1 \\
\text { sa } \\
\mathrm{mp} \\
\text { ai } \\
2 \\
\mathrm{kal} \\
\mathrm{i}\end{array}$ & $\begin{array}{l}\text { Tid } \\
\text { ak } \\
\text { ada }\end{array}$ & \\
\hline $\begin{array}{l}\text { Bagaimana anda } \\
\text { menilai kontrol asma } \\
\text { anda selama } 4 \text { minggu } \\
\text { terakhir }\end{array}$ & $\begin{array}{l}\text { Tid } \\
\text { ak } \\
\text { ter } \\
\text { ko } \\
\text { ntr } \\
\text { ol }\end{array}$ & $\begin{array}{l}\text { Kont } \\
\text { rol } \\
\text { yang } \\
\text { buru } \\
\mathrm{k}\end{array}$ & $\begin{array}{l}\text { Agak } \\
\text { terkendal } \\
\mathrm{i}\end{array}$ & $\begin{array}{l}\text { Ko } \\
\text { ntr } \\
\text { ol } \\
\text { ya } \\
\text { ng } \\
\text { bai } \\
\text { k }\end{array}$ & $\begin{array}{l}\text { Sep } \\
\text { enu } \\
\text { hny } \\
\text { a } \\
\text { terk } \\
\text { ont } \\
\text { rol }\end{array}$ & \\
\hline
\end{tabular}

Sumber: Nathan, 2012. 


\section{Metode Penelitian}

\subsection{Rancangan Penelitian}

Jenis penelitian yang digunakan adalah penelitian case study dengan desain penelitian pre and post test yaitu membandingkan antara skor sebelum dan sesudah intervensi Incentive Spirometry dan Chest Therapy.

\subsection{Tempat dan Waktu}

Penelitian dilakukan di laboratorium D-III Fisioterapi Universitas Abdurrab Pekanbaru, pada tanggal Waktu penelitian dilaksanakan dari tanggal 04 Februari 2020 hingga 02 April 2020.

\subsection{Teknik Pengambilan Sampel}

Dalam penelitian ini teknik pengambilan sampel yang digunakan adalah teknik purposive sampling yaitu teknik sampling non random sampling dimana peneliti menentukan pengambilan sampel dengan cara menetapkan ciri-ciri khusus yang sesuai dengan tujuan penelitian sehingga diharapkan dapat menjawab permasalahan penelitian. Sampel yang terpilih menjadi subjek penelitian diberikan penjelasan mengenai tujuan penelitian, manfaat penelitian serta diberikan penjelasan mengenai program penelitian yang akan dilakukan. Sampel yang bersedia mengikuti program penelitian diminta mengisi informed consent.

\subsection{Prosedur Intervensi}

Langkah-langkah yang diambil dalam prosedur penelitian ini dibagi menjadi tiga bagian yaitu: prosedur administrasi, prosedur pemilihan sampel dan Tahap pelaksanaan penelitian.

1) Prosedur administrasi

Prosedur administrasi dilakukan disini menyangkut: (1) Persiapan surat informed consent persetujuan sampel mengikuti program penelitian dan memberikan informasi terkait pelaksanaan program penelitian, (2) Mempersiapkan blangko-blangko dan alat pengukuran yaitu Asthma control test kuisoner untuk mengukur derajat kekambuhan pada asma bronkial. (3) Mengisi blangko-blangko penelitian untuk diisi identitas diri dan mengumpulkan kembali.

2) Prosedur Pemilihan Sampel

Prosedur pemilihan sampel yang memenuhi kriteria inklusi dan eksklusi dari jumlah populasi. Jumlah sampel 1 (satu) orang yang diberikan Incentive Spirometry dan Chest Therapy.

3) Tahap Pelaksanaan Penelitian

Tahap pelaksanaan penelitian menyangkut: (1) Menyiapkan form pengukuran. (2) Membuat jadwal pengambilan data. (3) Intervensi dilakukan selama 6 (enam) minggu dengan intensitas 2 kali seminggu. (4) Setelah mendapatkan treatment selanjutnya dilakukan evaluasi menggunakan Asthma control test kuisoner untuk mengukur derajat kekambuhan pada asma bronkial.

\section{Hasil Percobaan}

\subsection{Hasil dan Pembahasan}

a. Hasil

Gambaran umum sampel dalam studi kasus ini adalah seseorang dengan karakteristik dari pasien yang menderita asma bronkial persisten sedang. Dengan aplikasi chest therapy dan volumetric incentive spirometry untuk mengurangi gejala kekambuhan. Proses penelitian ini berlangsung kurang lebih 2 bulan yang dilakukan 2 kali dalam seminggu. Terapi dimulai pada tanggal 04 Februari 2020 s/d 02 April 2020, didapat bahwa pasien positif mengalami asma bronkial persisten sedang yang dilakukan pemeriksaan dengan incentive spirometry dan terjadi peningkatan gejala kekambuhan serta tidak terkontrolnya asma yang diukur dengan menggunakan asthma control test. Setelah peneliti melakukan intervensi chest therapy 
dan volumetric incentive spirometry sebagai terapi latihan utama dalam penanganan untuk mengetahui keberhasilan intervensi terhadap penurunan gejala kekambuhan.

Hasil penelitian pelaksanaan fisioterapi yang telah dilakukan selama 2 bulan didapatkan hasil;

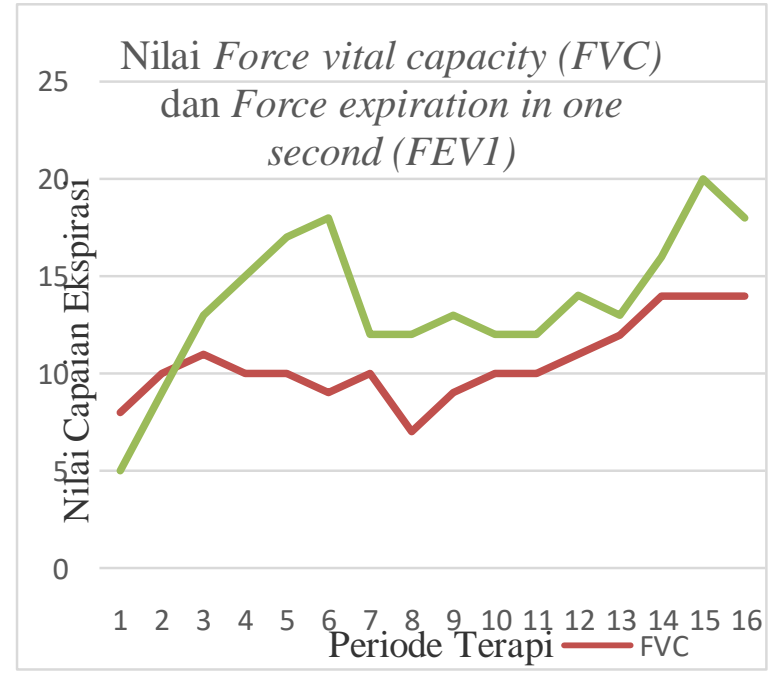

Hasil Evaluasi menggunakan kuisioner asthma control test diawal didapatkan skor 17 setelah diberikannya treatment sebanyak 16 kali terapi didapatkan hasil dengan skor 22 . Berdasarkan hasil tersebut terdapat peningkatan kontrol asma dengan berkrangnya gejala kekambuhan.

\section{b. Pembahasan}

\section{1) Efek Chest therapy dan Incentive} Spirometry terhadap pengurangan gejala kekambuhan.

Asma bronkial merupakan penyakit paru obstruksi kronik yang memiliki karakterisitik serangan periodik yang disebabkan kepekaan individu terhadap alergen yang memicu inflamasi/peradangan pada area bronkus. Peradangan ini memicu peningkatan jumlah sputum dan perubahan dalam saluran napas ditandai sesak napas (dispneu) disertai mengi, dada rasa tertekan dan batuk terutama malam hari. Disaat serangan asma terjadi penderita mengalami kesulitan melakukan inspirasi dan ekspirasi akibat sputum dan area bronkus yang membengkak menutup jalan napas, akibatnya penderita melakukan usaha yang besar untuk melakukan pernapasan dan aktifitas fungsional dapat terhenti akibat serangan asma yang terjadi. Peningkatan serangan asma memicu parahnya gejala yang timbul, inspirasi dan ekspirasi penderita menjadi pendek, penumpukan sputum pada area lobus paru, kekakuan pada rongga dada, penurunan nilai kapasitas dan volume pada paru-paru.

Berdasarkan permasalahan tersebut intervensi yang dapat diberikan oleh fisioterapi yaitu chest therapy dengan variasi postural drainage, tapotement, batuk efektif dan latihan pernapasan menggunakan incentive spirometry. Chest therapy adalah upaya preventif yang dilakukan untuk merawat berbagai kondisi pulmonal dengan teknik fisioterapi dada meliputi postural drainage, tapotement, dan batuk efektif. Pemberian chest therapy efektif dalam pembersihan jalan napas dimana pemberian posisi dengan gravitasi maksimal dan tepukan ringan pada dada membantu melepaskan sputum yang melekat pada area lobus dan dikeluarkan melalui sistem batuk ${ }^{(18)}$. Incentive spirometry mengendalikan perubahan fungsi pernapasan, Berdasarkan penelitian Sitti Nurun Nikmah (2014), dengan latihan incentive spirometryselain dapat meningkatkan kekuataan otot inspirasi secara maksimal, juga mampu membantu pengeluaran dahak, sehingga efisiensi napas dapat diperbaiki dan juga berdampak pada perbaikan kualitas hidup. Perbaikan asupan dan perfusi oksigen ke dalam darah. Peningkatan kapasitas dan volume paru-paru, saturisasi oksigen arteri dengan mekanisme sustained maximal inspiration (SMI). Peningkatan kapasitas dan volume paru-paru mengindikasikan perbaikan fungsi yang berkelanjutan pada pengurangan gejala kekambuhan pada pasien. Perubahan jalan napas akibat penumpukan sputum sebagai respon terhadap allergen yang menyebabkan gejala khas pada kondisi asma bronkial yaitu sesak napas (dispneu) saat 
inspirasi dan ekspirasi diketahui mengalami penurunan melalui berkurangnya intensitas serangan asma dan meningkatnya Force vital capacity dan Force expiration in one second (FEV'). Hal ini diketahui dengan evaluasi asthma control test dimana pasien mengalami penurunan gejala kekambuhan saat serangan asma terjadi.

\section{KESIMPULAN}

Berdasarkan hasil penelitian yang dilakukan pada pasien dengan kondisi Asma bronkial persisten sedang dengan menggunakan intervensi chest therapy dan incentive spirometry untuk penurunan gejala kekambuhan yang diberikan selama 2 bulan, dilakukan 16 kali terapi dan dievaluasi sebanyak 2 kali menggunakan pengukuran Asthma Control Test. Pada terapi pertama dilakukan evaluasi pertama dan di dapatkan hasil skor ACT 17 (asma tidak terkontrol) dan setelah dilakukannya terapi sebanyak 16 kali di evaluasi ke 2 didapatkan dengan skor ACT 22 (asma terkontrol sebagian).

Dengan demikian maka dapat disimpulkan bahwa pada kondisi Asma bronkial persisten sedang yang dievaluasi dengan menggunakan Asthma Control Test dengan pemberian intervensi Chest therapy dan Incentive spirometry dapat mengurangi gejala kekambuhan.

\section{REFERENSI}

[1,5]Nakagome, Kazuyuki. 2011. Pathogenesis of Airway Inflammation in Bronchial Asthma. Auris Nasus Larynx: 556563.

[2,7] Nikmah, Sitti. et.al. 2014. Efektivitas Latihan Incentive Spirometry Dengan Latihan Pernapasan Diafragma Terhadap Fungsi Paru, Kapasitas fungsional, Dan Kualitas Hidup Penderita Asma Bronkial Alergi. MKB Vol. 46: 39-47.
[3]. Wijaya, Ardi. 2018. Sistem Pakar Diagnosis Asma Dengan Menggunakan Algoritma Genetik. Jurnal Pseudocode Vol 2, ISSN: 2335-5920: 01-11.

[4]. Malik, Rajni. 2014. Fisioterapi Kardiopulmonal. Jaypee Brothers Medical Publisher

[6.] Kartikasari, Dian. 2019. Latihan

Pernapasan Diapragma Meningkatkan

Arus Puncak Respirasi dan

Menurunkan Frekuensi Kekambuhan

Asma. Jurnal Keperawatan Indonesia: 53-64

[8]. Eltorai, E. M. Adam, et. al. 2018. Utility of Inspiratory Volume in Incentive Spirometry. Rhode Island Medical Journal: $37-40$.

[9]. Unaiyah, Anna. et.al. 2014. Spirometri. Ina J Chest Crit and Emerg Med Volume 1: 35-38.

[10]. Aryayuni, C. 2015. Pengaruh Fisioterapi Dada Terhadap Pengeluaran Sputum pada Anak dengan Penyakit Gangguan Pernapasan di Poli Anak RSUD Kota Depok. Jurnal Keperawatan Widya Gantari: 31-42.

[11]. Hendra,et. al. 2011. Pengaruh Mobilisasi dan Fisioterapi Dada Terhadap Kejadian Ventilator Asscoiated Pneumonia di Unit Perawatan Intensif. Ners Jurnal Keperawatan Volume 7: 121-129.

[12. 14, 16, 18]. Purnomo, Didik. 2014. Pengaruh Infra Red dan Terapi Latihan Terhadap Penderita Asma Bronchiale. Jurnal Widya Husada Semarang: 22-30.

[13]. Herdyani, Putri, et. al. 2014. Perbedaan Postural Drainage dan Latihan Batuk Efektif pada Intervensi Nebulizer Terhadap penurunan Frekuensi Batuk pada Asma Bronchiale Anak 3-5 Tahun. Jurnal Fisioterapi Volume 13 nomor I: 01-11. 
Jurnal Ilmiah Fisioterapi (JIF) Volume 3 nomor 02, Agustus 2020

[15]. Manzoor, F. 2012.Effect of Postural Drainage Physical Therapy Techniques on In-Patient Management of Pneumonia . Rawal Medical Journal: Vol 37: 250-252.

[17]. Sabri, S. Yessy. 2014. Penggunaan Asthma Control Test (ACT) Secara Mandiri oleh Pasien untuk Mendeteksi Perubahan Tingkat Kontrol Asmanya. Jurnal Kesehatan Andalas: 517-526. 